Van der Moezel, P. G., G. V. N. Pearce-Pinto and D. T. BELL (1991): Screening for salt and waterlogging tolerance in Eucalyptus and Melaleuca species. Forest Ecology and Management 40, 27-37.

WILLI, Y. and J. BUSKIRK (2005): Genomic compatibility occurs over a wide range of parental genetic similarity in an outcrossing plant. Proceedings of the Royal Society of London. Series B, Biological Sciences. Royal Society, London, 272: 1333-1338.

Williams, D. R., B. M. Potts and P. G. Black (1999): Testing single visit pollination procedures for Eucalyptus globulus and E. nitens. Australian Forestry 62: 346-352.
YANCHUK, A. D. (2001): A quantitative framework for breeding and conservation of forest tree genetic resources in British Columbia. Canadian Journal of Forest Research 31: 566-576.

Zobel, B. J. and J. TAlberT (1984): Applied Forest Tree Improvement, Wiley, New York.

ZOHAR, Y. (1991): Performance of seedlings from selected sources of Eucalyptus occidentalis in a semi-arid Mediterranean-type environment. South African Forestry Journal 159: 37-41.

\title{
Genetic structure and diversity of Polylepis australis (Rosaceae) tree populations from central Argentina: Implications for forest conservation
}

\author{
By N. B. Julio ${ }^{1)}$, J. C. RondAn DueÑas ${ }^{1)}$, D. Renison ${ }^{2), *}$ and I. Hensen ${ }^{3)}$
}

(Received $4^{\text {th }}$ September 2009)

\begin{abstract}
Worldwide, large areas of forest are being transformed to other land cover types and the resulting fragmented populations may suffer from restricted gene flow leading to genetic pauperization and increased inbreeding. To assess the genetic constitution of fragmented Polylepis australis mountain forests of central Argentina, analyses of the structure and diversity of ISSR markers were carried out for 90 trees distributed throughout five river basins with differing degrees of fragmentation. Overall, average polymorphism $(P)$ ranged between 87.2 and $94.9 \%$ (95\% criterion) while marker diversity index $(M)$ varied between 0.35 and 0.39 ; values which are comparable with other wind-pollinated tree species. Analysis of molecular variance (AMOVA) revealed that most genetic variation occurred within river basins $(97.8 \%)$, with only a little occurring between river basins $(2.2 \%$; $\Phi_{S T}=0.02$ ). In addition, Mantel's test indicated that $P$. australis does not follow the usual pattern of isolation by distance; instead the UPGMA method showed that trees from the two most degraded river basins formed a group while trees from the three better pre-

1) Cátedra de Genética de Poblaciones y Evolución, Universidad Nacional de Córdoba. Velez Sarsfield 299, 5000 Córdoba, Argentina.

2) Centro de Ecología y Recursos Naturales Renovables Dr. Ricardo Luti (CERNAR), Facultad de Ciencias Exactas, Físicas y Naturales, UNC - CONICET, Av. Vélez Sarsfield 1611, X5016GCA Córdoba, Argentina.

$\left.{ }^{3}\right)$ Institute of Biology, Geobotany and Botanical Garden. MartinLuther-University Halle-Wittenberg, Am Kirchtor 1, D-06108 Halle, Germany.

*) Corresponding author: Fon 54-351-4334141.

E-mail addresses: darenison@yahoo.com.ar danielrenison@ecosistemasarg.org.ar
\end{abstract}

served basins formed another. As such, either effective pollen flow has maintained high levels of genetic diversity, or present day genetic variability is a remnant of a recently fragmented ancestral panmictic population. We conclude that, at present, genetic degradation in $P$. aus tralis populations of central Argentina is not as important as ecological degradation - such as soil loss, intensive browsing by livestock or increased frequencies of wildfires, and that genetic variability is still fully available for forest restoration.

Key words: fragmentation, genetic diversity, Polylepis australis, Argentina, conservation, ISSR.

\section{Introduction}

Worldwide, large areas of forest are being been felled for timber, burnt or clear-cut to produce grasslands for livestock, agricultural lands or urban areas, all of which are changing the face of forest landscapes across the globe (CINGOLANI et al., 2008; ZAK et al., 2004; SPIES, 1998; EllenBerG, 1979). The resulting fragmented forest landscapes may have tree populations with diminished effective population sizes, decreased gene flow and increased inbreeding and eventually may produce high differentiation among remnant populations (JUMP and PEÑUELAS, 2006). However, this pattern has exceptions, as some species compensate fragmentation with increased gene flow through greater pollen or seed dispersal distances (FRANKHAM et al., 2002). Determining the genetic structure of fragmented tree populations is necessary for detecting any possible genetic loss due to inbreeding within fragments and for planning any adequate restoration action with regards to genetic differentiation and variability. Forest restoration is important 
because of the goods and services forests provide to humans such as timber, carbon capture, control of soil loss, increasing water catchment capacity of the area and provision of suitable habitat for wildlife (SPIES, 1998; KELTY, 1997; FJELDSÅ and KESSLER, 1996).

The Polylepis forests of the Andean highlands are one of South America's most endangered forest ecosystems. Forests were destroyed on a large scale during centuries of recurrent burning, which was used to claim agricultural land. At present, nearly all Polylepis stands throughout South America are still used for firewood, timber or as pasture land, which substantially affects their structure, species composition, regeneration and soil protection capacity (RENISON et al., 2011; 2010; 2006; Torres et al., 2008; Hensen, 2002; Kessler and DRIESCH, 1993). The genus Polylepis (Rosaceae) includes about 28 wind-pollinated species of short to tall shrubs and trees, which are distributed from Venezuela to Argentina (Kessler and Schmidt-Lebuhn, 2006; SCHMIDT-LEBUHN et al., 2006a). Some species grow in tropical alpine forests while others form isolated stands far above the treeline at altitudes reaching $5200 \mathrm{~m}$ asl., where they form the world's highest woodlands. This peculiar distribution exemplifies the distribution of many mountain woodlands and is mainly the result of a reduction of former extensive forests (CINGOLANI et al., 2008; RENison et al., 2006; HENSEN, 2002; ElLENBERG, 1979).

Polylepis australis is the southernmost species of the genus and it dominates the canopy of most tree line forests in the easternmost subtropical mountains of Argentina. Its distribution range extends to about 1200 $\mathrm{km}$ from the mountains of central Argentina to the Andes in northern Argentina. As has occurred with other Polylepis species, in central Argentina the area occupied has been reduced to less than $20 \%$ of its prehuman extent due to 400 years of grazing by domestic livestock and frequent fires lit to produce new-growth (CINGOLANI et al., 2008; RENISON et al., 2006). A previous study using RAPD and ISSR markers showed a reduction in genetic connectivity between two forest fragments in younger, but not in older trees (JULIO et al., 2008), suggesting that other forest fragments may have lost genetic connectivity entirely, and/or that they may lose it in the future. To date, to the best of our knowledge, only SchmidT-LeBUHN et al. (2006b) revealed high gene flow between stands along with a lack of genetic structuring for $P$. rugulosa and $P$. tarapacana in Chile, but their results have to be taken with caution as they were only based on a low number of samples per population.

With a view to developing conservation and restoration strategies, we analysed the extent and consequences of fragmentation and habitat degradation on the genetic structure of remaining $P$. australis trees occupying 5 river basins in the mountains of central Argentina, differing in size and degree of conservation. For this purpose, Inter-Simple Sequence Repeat (ISSR) markers were used (ZIETKIEWICZ et al., 1994), as these yielded high levels of polymorphism in a previous study (Julio et al., 2008). Molecular markers have been frequently used to investigate the genetic structure within and between populations (NYBOM, 2004; BARTISH et al., $2000)$ and to estimate effects of fragmentation (FrANKHAM et al., 2002).

\section{Materials and Methods}

\section{Study area}

The study was carried out in the Mountains of central Argentina (Province of Córdoba, N-S orientation, 1400 to $2800 \mathrm{~m}$ asl.; centered around $31^{\circ} 34^{\prime} \mathrm{S}$; $64^{\circ} 50^{\prime} \mathrm{W}$; Fig. 1). The mean annual temperatures range from $13.2^{\circ} \mathrm{C}$ at $1500 \mathrm{~m}$ asl. to $7.4^{\circ} \mathrm{C}$ at $2700 \mathrm{~m}$ (MARCORA et al., 2008). Mean annual precipitation is $924 \mathrm{~mm}$, with most rainfall concentrated in the warmer months, between October and April (CoLLADON et al., 2009). Vegetation consists of a mosaic of tussock grasslands, grazing lawns and Polylepis australis forests which now occupy $12 \%$ of the area (CINGOLANI et al., 2004). We chose five river basins - which in RENISON et al. (2006) were categorized according to the different land use histories and consequent varying levels of fragmentation and conservation - from the least to the most preserved as (1) Mina Clavero, (2) Yuspe, (3) Condorito, (4) Los Molles and (5) Santa Clara river basins - with Polylepis cover of $1,3,6,15$ and $15 \%$, respectively. Further descriptions and historical land use information may be found in RENISON et al. (2011; 2010; 2006).

\section{Sample collection}

Leaf samples were obtained in 2005 from a total of 18 trees per river basin. Trees were separated by at least $200 \mathrm{~m}$ to minimize the chance of sampling closely related or genetically identical individuals. The minimum distance between the centres of two basins was 14 $\mathrm{km}$, with the maximum distance being $65 \mathrm{~km}$ (Fig. 1, Table 3).

\section{DNA extraction and ISSR-PCR procedures}

Genomic DNA was extracted from leaf tissue of $P$. australis using columns of the "QIAGEN DNeasy Plant Minikits" following the manufacturer's instructions. A total of 16 ISSR primers were screened using a representative subset of the $P$. australis samples. Three of them (Pa1((GA)8C), Pa2((GTT)5ST) and Pa3(CCA)) were selected on the basis of the number, spacing and intensity of bands amplified, as well as the degree of polymorphisms revealed (Pa1: 14 bands, Pa2: 12 bands and Pa3: 13 bands). The reaction mix was prepared as described by BORNET and BRANCHARD (2001) as follows: each $25 \mathrm{\mu l}$ PCR reaction contained $1 \mathrm{X}$ PCR buffer (50 mM KCl,10 mM Tris-HCl pH 9), $2.5 \mathrm{mM} \mathrm{MgCl}_{2}$, $0.2 \mathrm{mM}$ of each four dNTPs, $10 \mathrm{pmol}$ of each primer, $0.6 \mathrm{U}$ of Taq polymerase (Amersham) and $10 \mathrm{ng}$ of DNA of $P$. australis. DNA was amplified using a programmable thermal cycler (Eppendorf Mastercycler) with the following program: $3 \mathrm{~min}$ at $94^{\circ} \mathrm{C}$ for the initial denaturation, followed by 35 cycles consisting of denaturation $\left(30 \mathrm{~s}\right.$ at $\left.93^{\circ} \mathrm{C}\right)$, annealing $\left(1 \mathrm{~min}\right.$ at $\left.50^{\circ} \mathrm{C}\right)$, extension ( $1 \mathrm{~min} 30 \mathrm{~s}$ at $72^{\circ} \mathrm{C}$ ) and a final extension for $10 \mathrm{~min}$ at $72^{\circ} \mathrm{C}$. PCR products were analyzed by electrophoresis in $1 \%$ agarose gels with a TBE buffer system at $6 \mathrm{~V} / \mathrm{cm}$ for 3 hours and stained with $0,005 \mu \mathrm{g} / \mathrm{ml}$ ethidium bromide. 


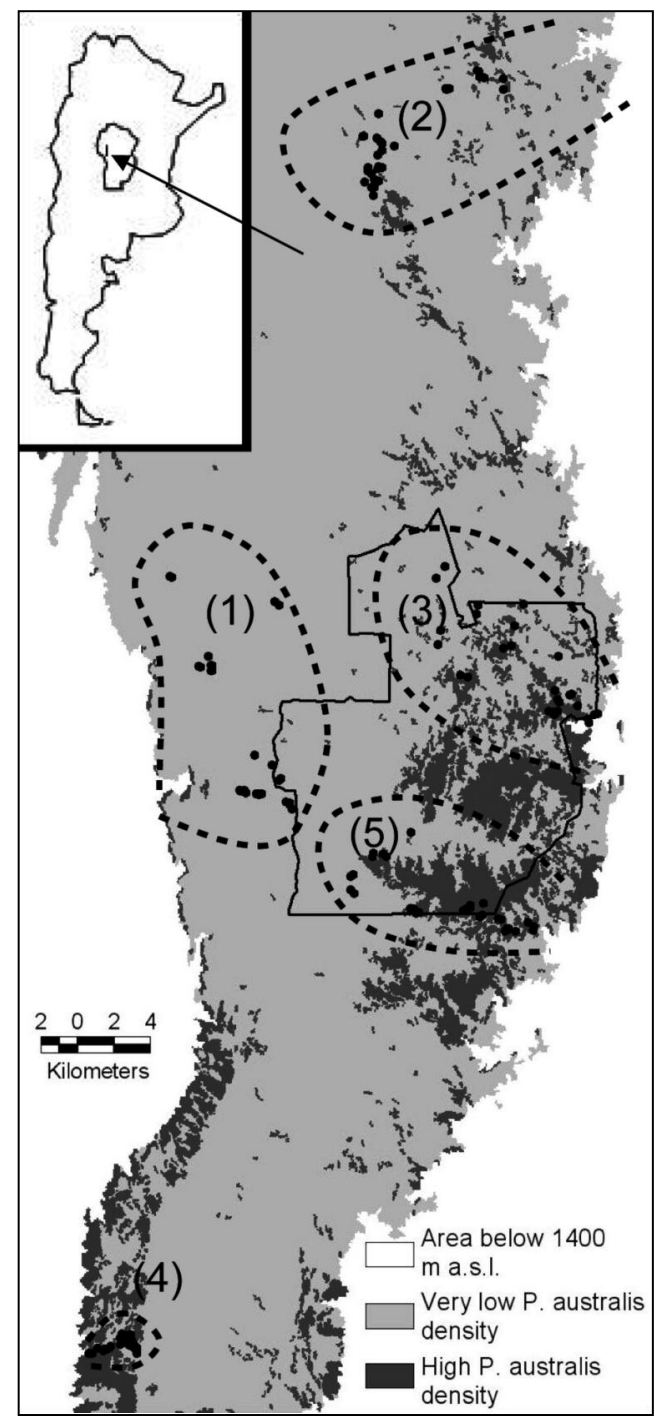

Figure 1. - Map of the mountains of central Argentina with sampled Polylepis australis tree locations marked as solid circles. Approximate shape and location of study river basins is shown in dotted lines and were numbered from worst to best conservation status as (1) Mina Clavero, (2) Yuspe, (3) Condorito, (4) Los Molles and (5) Santa Clara. Continuous line shows the boundaries of Quebrada del Condorito National Park. The top left map shows study location within the Province of Córdoba and Argentina.

Fragments were observed and photographed under UV light. In order to ensure reproducibility, several samples were run in at least two independent ISSR PCRs.

\section{Statistical methods}

Genetic diversity within river basins (populations) was represented as the percentage of polymorphic ISSR bands (ISSR polymorphic bands / total bands), calculated with the TFPGA program (MILLER, 1997). To compare $P$ values among river basins, confidence intervals were obtained by 'bootstrapping' using the InfoGen program (BALZARINI and DI RIENZO, 2004).

Because allelic frequencies can only be calculated assuming Hardy-Weinberg equilibrium and this information is not available through ISSR markers, we performed analyses that do not require band frequencies to be converted to allelic frequencies; namely, the Marker Diversity index $(M)$ (KAPRALOV et al., 2006), defined analogously to heterozygosity (NEI, 1978). Marker diversity index $(M)$ estimates the proportion of unmatched ISSR bands between pairs of individuals $(M)$ within populations. We calculated $M$ for each pair of individuals and then averaged all $M$ values obtained within each population. In order to compare the genetic diversity indices of the different populations, nonparametric Kruskal-Wallis tests were performed using the Infostat program (DI RIENZO et al., 2003).

From the matrix of presence/absence of ISSR fragments, a matrix of genetic distances between pairs of individuals was constructed using simple matching similarity coefficients (1\% matching) with the RAPDPLOT 3.0 program (BLACK, 1997). Similarity matrices were utilized to construct the UPGMA (unweighted pair-group method with arithmetic average) dendrogram using PHYLIP (Phylogeny Inference Package Version 3.57c, FELSENSTEIN, 1993). We estimated the statistical stability of the branches in the cluster by bootstrap analysis with 1,000 replicates.

To quantify genetic structure we examined genetic variation within and among populations by means of molecular variance analysis (AMOVA; ExCOFFIER et al., 1992) using ARLEQUIN (SCHNEIDER et al., 1997). The level of differentiation between pairs of river basins was calculated with the $\Phi_{S T}$ index - which is analogous to $F_{S T}$ (WRIGHT, 1978) and is a measure of the variance in allelic frequencies (or phenotypic diversity, in this case) - calculated in the AMOVA.

When performing calculations with ISSR data, the components of the variances corresponded to phenotypic, rather than to genotypic variation, and thus the assumptions of Hardy-Weinberg-Equilibrium (no mutation, migration, or selection) were not required. We estimated the effective number of migrants per generation by the formula $N_{e} m=(1 / \phi s t-1) / 4$ (WRIGHT, 1951), based on $\phi$ statistics, and we performed the correlation analysis between geographical and genetic distance matrices (normalized Mantel Z statistic) using ISOLDE of the GENEPOP statistical package (RAYMOND and ROUSSET, 1995).

\section{Results}

The three ISSR primers used yielded a total of 39 loci in Polylepis australis individuals from the five river basins. Of these, 38 were polymorphic and were used in our analysis. Our data revealed high diversity within river basins (Table 1), as average $P$ values ranged between $92.3 \%$ and $90.8 \%$, under $95 \%$ and $99 \%$ criterion respectively. Differences in $P$ among river basins were not significant, but differences in the $M$ index among trees within river basins were significant $(p<0.01)$, with slightly higher diversity indexes in the two most degraded basins (Mina Clavero and Yuspe) and in one of the better preserved basins (Santa Clara; Table 1). The partitioning of $P$. australis genetic variation for five river basins, examined by AMOVA analysis, showed that most of the variability $(97.8 \%)$ was attributable to differences within river basins, while only a 
Table 1. - Genetic diversity index in Polylepis australis; \%P, percent of polymorphic loci using for the calculations of 99 and $95 \%$ of the most frequent loci; $M$, phenotypic heterogeneity calculated by marker diversity, in bold we highlight the three highest indexes.

\begin{tabular}{llll}
\hline \multicolumn{1}{c}{ Populations } & \multicolumn{2}{c}{$\% P$} & $M$ \\
\cline { 2 - 3 } (River Basins) & $99 \%$ & $95 \%$ & \\
\hline 1. Mina Clavero & 94.87 & 94.87 & $\mathbf{0 . 3 9}$ \\
\hline 2. Yuspe & 94.87 & 92.30 & $\mathbf{0 . 3 9}$ \\
\hline 3. Condorito & 89.74 & 87.17 & 0.35 \\
\hline 4. Los Molles & 89.74 & 89.74 & 0.36 \\
\hline 5. Santa Clara & 92.30 & 89.74 & $\mathbf{0 . 3 9}$ \\
\hline Average & 92.30 & 90.76 & 0.38 \\
\hline
\end{tabular}

$M ;(\mathrm{p}<0.01)$

low but significant proportion $(2.2 \%, p<0.01$; Table 2$)$ was attributable to differences between river basins.

The overall $\phi_{S T}$ value of 0.022 indicates a low but significant $(\mathrm{p}<0.05)$ level of genetic differentiation among river basins. The effective number of migrants per generation $\left(N_{e} m\right)$ roughly estimated from $\Phi_{S T}$ was 10.9 . The comparison of pairwise $\phi_{s}$ values derived from AMOVA shows that five of the ten differences among river basins were significant (Table 3).

In order to examine the relationships between the five river basins, we used similarity matrices (Table 3) to construct a UPGMA dendrogram (Fig. 2). The cluster revealed two groups of river basins, albeit with low bootstrap support (52\%, with 1000 replicates). The first group included the two most degraded river basins of Mina Clavero (1) and Yuspe (2); while the second group included the better preserved river basins of Condorito (3), Los Molles (4) and Santa Clara (5). The regression analysis between genetic and geographical distances

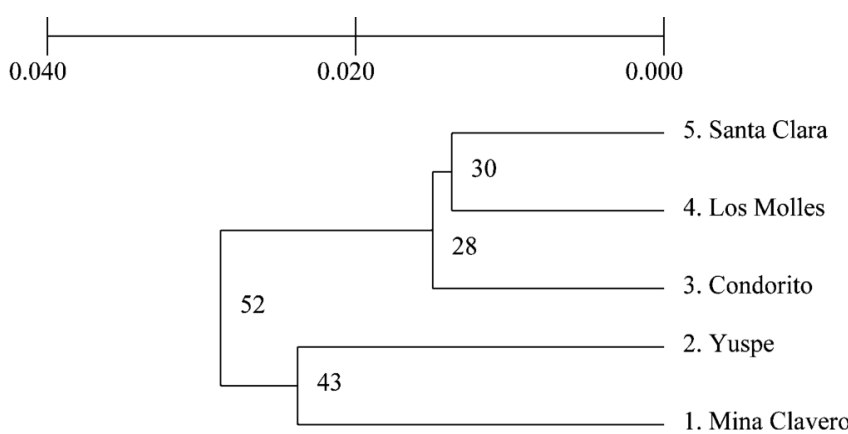

Figure 2. - Phenogram summarizing the genetic distances (according to NEI, 1972) between five populations of Polylepis australis. Numbers at the nodes indicate the percentage of times that the group was present in 1000 bootstrap replications.

(Mantel's test, $r=0.1609 ; p=0.75$ ) was not significant, suggesting that $P$. australis does not conform to a pattern of isolation by distance.

\section{Discussion}

The overall means of polymorphic bands $(P=92.3 \%)$ found in this analysis were in accordance with those reported for Polylepis australis by JULIO et al., (2008: ISSR, $P=89-91 \%$ ) and SELTMANN et al., (2009b: RAPD, $P=75-82 \%)$. The similar values of $P$ at different criteria indicates that alleles in several loci are present in similar frequencies throughout the whole population, which is presumably promoted by a high degree of gene flow $(\mathrm{Nm}=10.9)$. Moreover, levels of genetic variability of the most degraded $P$. australis populations of Mina Clavero and Yuspe, which were characterized by isolated trees or small forest patches (TORRES et al., 2008; RENISON et al., 2006; CingOLANI et al., 2004), were similar or even higher than other well conserved populations.

Table 2. - Analysis of molecular variance (AMOVA) for 90 Polylepis australis individuals grouped into five populations ( $\mathrm{P}$ based on 1000 permutations).

\begin{tabular}{lccccc}
\hline Source of variation & d.f. & Sum of & Variance & Percentage of & $\mathrm{P}$ \\
& & square & components & variation & \\
\hline Among populations & 4 & 37.200 & $0.150 *$ & 2.24 & 0.007 \\
\hline Within populations & 85 & 559.556 & 6.583 & 97.76 & \\
\hline Total & 89 & 596.756 & 6.583 & & \\
\hline
\end{tabular}

${ }^{*} \mathrm{p}<0.01$.

Table 3. - Matrix between genetic distance (pairwise $\phi_{S T}$ values; lower left triangle) and geographic distances (km; upper right triangle) among the five Polylepis australis. Basins ordered by conservation status from worst to best (1) Mina Clavero, (2) Yuspe, (3) Condorito, (4) Los Molles and (5) Santa Clara.

\begin{tabular}{llllll}
\hline & 1 & 2 & 3 & 4 & 5 \\
\hline 1. & 0 & 30.2 & 14.5 & 35.8 & 15.7 \\
\hline 2. & $0.0349 *$ & 0 & 29.0 & 64.6 & 40.5 \\
\hline 3. & 0.0173 & 0.0031 & 0 & 42 & 14.3 \\
\hline 4. & $0.0415^{*}$ & 0.0213 & $0.0292 *$ & 0 & 29.2 \\
\hline 5. & $0.0419 *$ & 0.0148 & $0.0286 *$ & 0.0184 & 0 \\
\hline$* 0.05$. & & & & &
\end{tabular}


Both SELtmann et al. (2009a) and Schmidt-LebuHn et al. (2006b) suggest reproductive and genetic connectivity for $P$. australis forest fragments through long-distance wind dispersal of pollen - which may explain the results found in this study. Our results are also in accordance with several reviews that showed that wind pollinated tree species have a high proportion of genetic variability within populations and a clearly lower diversity among populations (NYBOM, 2004; NYBOM and BARTISH, 2000; HAMRICK et al., 1992), and that wind-pollinated trees might be less vulnerable than other trees regarding habitat fragmentation (KRAMER et al., 2008; JUMP and PEÑUELAS, 2006). A high amount of gene flow was also assumed by SCHMIDT-LEBUHN et al. (2006b) for the wind pollinated Polylepis rugulosa and Polylepis tarapacana. We rejected seed dispersal as a mechanism maintaining $P$. australis polymorphism as their wind dispersed seeds mostly travel short distances of less than $6 \mathrm{~m}$ (ZimMERMANN et al., 2009; TORREs et al., 2008).

As only adults were sampled, the levels of variability found in this analysis only reflect past population structures, and do not account for more recent changes. So an alternative explanation for the high estimated $P$ and $\mathrm{Nm}$ values would be that the five sampled populations are fragments of an ancestral panmictic population which was fragmented relatively recently and the effects of genetic drift are still not detectable. The indirect method for estimating the average amount of gene flow based on Wright's $F_{S T}$, despite providing robust estimates of $\mathrm{Nm}$, is not suitable to distinguish whether the differences between populations are the result of current or historical gene flow (SLATKIN and MADDISON, 1989). Furthermore, the persistence of multiple generations within populations as observed in the field (RENISON et al., 2011) and the maintenance of locally important population sizes in the recent past may also contribute to the high levels of genetic variation detected in this study; therefore, present day effective fragmentation cannot be discounted.

The overall differentiation observed among river basins (calculated by $\Phi_{S T}$ ) was significant but clearly lower than the means reported by NYBOM and BARTISH (2000) for dicotyledons (0.36), long lived perennials (0.25), widespread (0.42), outcrossing (0.28) and late successional status species (0.21). Equally low fixation indices of $<0.1$ were found for several other wind-pollinated tree species, such as $Q$. petraea (LE CORRE et al., 1997), Q. calliprinos (SCHILLER et al., 2006), Fraxinus excelsior (HEUERTZ et al., 2001), and Betula pendula (RUSANEN et al. 2003). We were not able to analyze the mating system in the studied populations since we used dominant molecular markers, which do not allow for the quantifying of heterozygous genotypes; but SELTMANN et al. (2009 a; b) reported reduced seed mass, reduced seed germination and reduced genetic variability of the progeny when pollination took place within distances less than $20 \mathrm{~m}$. Their data indicate that individuals become related only within short distances (within fragments), causing population sub-structuring. However, our samples were collected more than $200 \mathrm{~m}$ apart from each other, thus genetic relatedness within our samples should not influence our results.
AMOVA analyses also support the results that in the central Argentinean mountain range, $P$. australis genetic variation is more prevalent within populations $(97.8 \%)$ than among them (2.2\%). Mantel's test $(r=0.1609 ; p=0.75)$ shows that genetic differentiation is not correlated with geographic distance, which confirms that $P$. australis populations do not conform to a pattern of isolation by distance. Despite not being well supported by bootstrap values, the dendrogram indicates a pattern of clustering indicative of similar polymorphism levels, but one which does not coincide with geographical distance.

The populations of Mina Clavero and Yuspe grouped according to their similarity in allele frequencies in spite of their geographic distance, and they possibly represent relicts of an ancestral panmictic population. Although at present these populations show low density, they have preserved relatively high levels of genetic diversity, since the fragmentation may have occurred quite recently. Several studies in the mountains of central Argentina suggest that low population densities in these basins are the result of human activity enhanced by the proximity to roads that provide easy access to the development of livestock (CINGOLANI et al., 2008; 2004; RENISON et al., 2011, 2010). The populations of the second group (Condorito, Molles, and Santa Clara) cluster together. They still form relatively extensive forests that exist under conditions of relatively low human impact, mainly because they are rather inaccessible (RENISON et al. 2010, 2006). However, it is not proper to assign a direct relationship between the genetic composition and the level of degradation until more studies are specifically designed to clarify this point.

Studies conducted by SELtmann et al. (2009b) in the same areas indicate that there has been no decline in the naturally deposited outcrossed pollen load in small $P$. australis forest fragments, and that isolated forest fragments are not subject to inbreeding depression through selfing. However, a molecular study in two fragments within the Yuspe and Los Molles basins (JULIO et al., 2008) found evidence of genetic fragmentation only in young trees, suggesting fragmentation effects might be a problem in the future; as has also been found in other South American trees where fragmentation has been recent (MATHIASEN et al., 2007). As genetic diversity plays an important role in the long term capacity to adapt to changing conditions, maintaining genetic diversity of tree species should indeed be a long-term conservation priority.

We conclude that in present day fragmented $P$. australis populations, ecological and non-genetic degradation are the main drivers of low reproductive success (Cingolani et al., 2008, REnison et al., 2011, 2010, 2006, 2005 and 2004), while genetic variability is still fully available for forest restoration.

\section{Acknowledgements}

We thank Prof. Dr. CRISTINA N. Gardenal (University of Córdoba, Argentina) for her advice, assistance in data analysis and for providing laboratory space; thanks to ANA M. Cingolani (University of Córdoba, Argentina) 
for help with Figure 1, to RICARDo SUAREZ and JULIO DOMINGUEZ who collected most of the genetic samples. Financial support was kindly provided by the Volkswagen Foundation. Permits to access their lands to collect samples were provided by the National Parks authorities and J. Nores, N. BAZAN, A. Moreno, J. Cuello, G. Estrada DE Ponce, M. López and R. GRAPH. Finally, thanks to ANDREA PREMOLI for her critical reading of the manuscript and to DANNY MCCluskey for checking our English.

\section{Reference list}

BALZARINI, M. and J. Di RIENZO (2004): InfoGen www.infogen.com.ar

Bartish I.V., L. P. Garkava, K. Rumpunen and H. Nybom (2000): Phylogenetic relationships and differentiation among and within populations of Chaenomeles Lindl. (Rosaceae), estimated with RAPD and isozymes. Theoretical and Applied Genetics 101: 554-563.

BLACK, W. C. (1997): FORTRAN programs for analysis of RAPD-PCR data.

BoRNET, B. and M. BRANCHARD (2001): Nonanchored Inter Simple Sequence Repeat (ISSR) markers: reproducible and specific tools for genome fingerprinting. Plant Molecular Biology Report 19: 2092-21. http://lamar. colostate.edu/pub/wbc4.

Cingolani, A. M., D. Renison, M. ZaK and M. Cabido (2004): Mapping vegetation in a heterogeneous mountain rangeland using Landsat data: an alternative method to define and classify land-cover units. Remote Sensing of Environment 92: 84-97.

Cingolani, A., D. Renison, P. Tecco, D. Gurvich and M. CABIDO (2008): Predicting cover types in a mountain range with long evolutionary grazing history: a GIS approach. Journal of Biogeography 35: 538-551.

Colladon L., G. G. Felici and I. Plazos (2009): Anuario pluviométrico 2000/01 - 2004/05. Síntesis 1992/93 2004/05. Cuenca del río San Antonio. Sistema del río Suquia-provincia de Córdoba. Instituto Nacional del Agua (INA), Centro de la Región Semiárida (CRSA).

Di Rienzo J. A., C. W. Robledo, M. G. BAlzarini, F. Casanoves and L. Gonzalez (2003): InfoStat www.infostat.com.ar

ELLENBERG, H. (1979): Man's influence on tropical mountain ecosystems in South America. Journal of Ecology 67: 401-416.

Excoffier, L., P. E. Smouse and J. M. Quattro (1992): Analysis of molecular variance inferred from metric distances among DNA haplotypes: application to human mitochondrial DNA restriction data. Genetics 131 479-491.

FELSENSTEIN, J. (1993): PHYLIP. Phylogeny inference package, version 3.5c. Department of genetics. University of Washington, Seattle, WA

FJELDSÅ, J. and M. KESSLER (1996): Conserving the biological diversity of Polylepis woodlands of the highlands of peru and Bolivia. Nordeco, Copenhagen.

Frankham, R., J. D. Ballow and D. A. Briscoe (2002): Introduction to conservation genetics. Cambridge, University Press.

HAMrick, J. L., J. O. GodT and S. L. ShERMAN (1992): Factors influencing levels of genetic diversity in woody plant species. New Forests 6: 95-124.
HENSEN, I. (2002): Impacts of anthropogenic activity on the vegetation of Polylepis woodlands in the region of Cochabamba, Bolivia. Ecotropica 8: 183-203.

Heuertz, M., J. F. Hausman, I. Tsvetkov, N. FrascariaLACOSTE and X. VeKEMANs (2001): Assessment of genetic structure within and among Bulgarian populations of the common ash (Fraxinus excelsior L.). Molecular Ecology 10: 1615-1623.

Julio, N. B., A. Sobral, J. Rondan Dueñas, J. Di Rienzo, D. RENisON and I. HENSEN (2008): RAPD and ISSR markers indicate diminished gene flow due to recent fragmentation of Polylepis australis woodlands in central Argentina. Biochemical Systematics and Ecology 36: $329-335$.

JUMP, A. S. and J. PEÑUELAS (2006): Genetic effects of chronic habitat fragmentation in a wind-pollinated tree. PNAS 103: 8096-8100.

Kapralov, M.V., T. M. Gabrielsen, I. E. Sarapultsev and C. Brochmann (2006): Genetic enrichment of the artic clonal plant Saxifraga cernua at its southern periphery via the alpine sexual Saxifraga sibirica. Molecular Ecology 15: 3401-3411.

KELTY, M. J. (1997): Silvicultural management of wildlife habitat, pp. 483-507. In: The practice of silviculture, edited by D. M. Smith, B. C. LARson, M. J. Kelty and P. M. S. Ashton, John Wiley press, New York.

Kessler, M. and P. DrIEsch (1993): Causas e historia de la destrucción de bosques Altoandinos en Bolivia. Ecología en Bolivia 21: 1-18.

Kessler, M. and A. N. Schmidt-Lebuhn (2006): Taxonomical and distributional notes on Polylepis (Rosaceae). Organisms, Diversity and Evolution 6: 67-70.

Kramer, A. T., J. L. Ison, M. V. Ashley and H. F. Howe (2008): The paradox of forest fragmentation genetics. Conservation Biology 22: 878-885.

Le Corre, V., S. Dumolin-Lapègue and A. Kremer (1997): Genetic variation at allozyme and RAPD loci in sessile oak Quercus petraea (Matt.) Liebl.: the role of history and geography. Molecular Ecology 6: 510-529.

Marcora P., I. Hensen, D. Renison, P. Seltmann and K. Wesche (2008): The performance of Polylepis australis trees along their entire altitudinal range: implications of climate change for their conservation. Diversity and Distributions 14: 630-636.

Mathiasen, P., A. E. Rovere and A. Premoli (2006): Genetic structure and early effects of inbreeding in fragmented temperate forests of a self-incompatible tree, Embothrium coccineum. Conservation Biology 21: 232-243.

MilleR, M. P. (1997): Tools for population genetic analyses (TFPGA) www.herb.bio.nau.edu/ miller/tfpga.htm.

NEI, M. (1978): Estimation of average heterozygosity and genetic distance from a small number of individuals. Genetics 89: $583-590$.

NyBom, H. (2004): Comparison of different nuclear DNA markers for estimating intraspecific genetic diversity in plants. Molecular Ecology 13: 1143-1155.

NyBom H. and V. BARTish (2000): Effects of life history traits and sampling strategies on genetic diversity estimates obtained with RAPD markers in plants. Perspectives in Plant Ecology, Evolution and Systematics 2: 93-114.

RAYMOND, M. and F. Rousset (1995): GENEPOP (version 1.2 population genetics software for exact test and ecumenicism. Journal of Heredity 86: 248-249. 
Renison, D., I. Hensen and A. M. Cingolani (2004): Anthropogenic soil degradation affects seed viability in Polylepis australis mountain forests of central Argentina. Forest Ecology and Management 196: 327-333.

Renison, D., A. M. Cingolani, R. Suarez, E. Menoyo, C. Coutsiers, A. Sobral and I. Hensen (2005): The restoration of degraded mountain woodlands: effects of seed provenance and microsite characteristics on Polylepis australis seedling survival and growth in Central Argentina. Restoration Ecology 13: 129-135.

Renison, D., I. Hensen, R. Suarez and A. M. Cingolani (2006): Cover and growth habit of Polylepis woodlands and shrublands in the mountains of central Argentina: human or environmental influence? Journal of Biogeography 33: 876-887.

Renison, D., I. Hensen, R. Suarez, A. M. Cingolani, P. MARCORA and M. A. Giorgis (2010): Soil conservation in Polylepis mountain forests of Central Argentina: Is livestock reducing our natural capital? Austral Ecology 35: $435-443$.

Renison, D., I. Hensen and R. Suarez (2011): Landscape structural complexity of high-mountain Polylepis australis forests: A new aspect of restoration goals. Restoration Ecology (online first: DOI: 10.1111/j.1526100X.2009.00555.x).

Rusanen, M., P. VAKKari and A. Blom (2003): Genetic structure of Acer platanoides and Betula pendula in northern Europe. Canadian Journal of Forest Research 33: $1110-1115$.

Schiller, G., G. Shklar, E. D. Ungar, A. Al-Omari, A. FAREed Zyadin and L. Korol (2006): Genetic diversity assessment by random amplified polymorphic DNA of oaks: 3. Quercus calliprinos Webb. in Israel and Jordan. Israel Journal of Plant Science 54: 137-154.

Schmidt-Lebuhn, A. N., M. Kessler and M. Kumar (2006a): Promiscuity in the Andes: Species relationships in Polylepis (Rosaceae, Sanguisorbeae) based on AFLP and morphology. Systematic and Botany 31: 547-559.

Schmidt-Lebuhn, A. N., M. Kumar and M. Kessler (2006b): An assessment of the genetic population structure of two species of Polylepis Ruiz and Pav. (Rosaceae) in the Chilean Andes. Flora 201: 317-325.

Schneider, S., J. M. KuefFer, D. RoEssli and L. ExcoffiER (1997): Arlequin ver 1.1: A software for population genetic data analysis. Genetics and Biometry Laboratory, University of Geneva. Switzerland.
Seltmann, P., D. Renison, A. Cocucci, I. Hensen and K. JUNG (2007): Fragment size, pollination efficiency and reproductive success in natural populations of wind-pollinated Polylepis australis (Rosaceae) trees. Flora 202: 547-554.

Seltmann, P., A. Coccucci, D. Renison, A. CierJacks and I. Hensen (2009a): Mating system, outcrossing distance effects and pollen availability in the wind-pollinated treeline species Polylepis australis BITT. (Rosaceae). Basic and Applied Ecology 10: 52-60.

Seltmann, P., I. Hensen, D. Renison, K. Wesche, S. Ploch, J. Roldan Dueñas, A. CocucCI and K. Jung (2009b): Biparental inbreeding depression, genetic relatedness and progeny vigor in a wind-pollinated treeline species in Argentina. Plant Ecology 205: 155-164.

Slatkin, M. and W. MAdDISON (1989): A cladistic measure of gene flow from the phylogenies of alleles. Genetics 123: $603-613$.

SPIES, T. (1998): Forest stand structure, composition, and function. Chapter 18. pp. 11-30. In: Creating a forestry for the $21^{\text {st }}$ century: The science of ecosystem management. Eds.: K. A. KoHM and J. F. FrankLIN. Island Press, Washington, D. C.

Torres, R. C., D. Renison, I. Hensen, R. Suarez and L. ENRICO (2008): Polylepis australis' regeneration niche in relation to seed dispersal, site characteristics and livestock density. Forest Ecology and Management 254: 255-260.

WRIGHT, S. (1951): The genetical structure of populations. Annals of Eugenics 15: 313-354.

WRIGHT, S. (1978): Evolution and the genetics of populations, vol. 4. Variability within and among natural populations. University of Chicago Press.

ZAK, M. R., M. CABIDo and J. G. Hodgson (2004): Do subtropical seasonal forests in the Gran Chaco, Argentina, have a future? Biological Conservation 120: 589-598.

ZietKIEWICZ, E., A. RAFALSKI and D. LABUdA (1994): Genome fingerprinting by simple sequence repeat (SSR)-anchored polymerase chain reaction amplification. Genomics 20: 176-183.

Zimmermann, H., D. Renison, I. Leyer and I. Hensen (2009): Do we need livestock grazing to promote Polylepis australis tree recruitment in the Central Argentinean Mountains? Ecological Research 24: 1075-1081. 